\title{
Literacki hołd poetów galicyjskich dla Józefa Dunina Borkowskiego
}

\section{Tadeusz Pó}

ORCID: 0000-0002-5225-2096

(Uniwersytet Rzeszowski)

Na łamach „Dziennika Mód Paryskich” 27 lipca 1842 roku Józef Dunin Borkowski zaapelował do Jana Nepomucena Kamińskiego, Aleksandra Fredry, Walentego Chłędowskiego, Wincentego Pola, Dominika Magnuszewskiego, Augusta Bielowskiego, Adama Garczyńskiego, Żegoty Pauliego, Stanisława Przyłęckiego, Jana Kantego Podoleckiego i Aleksandra Dunina Borkowskiego, żeby „pismami swymi wesprzeć zechcieli” pogorzelców Rzeszowa². Autor wezwania zmarł niecały rok później (I8 czerwca I843 roku), ale pozostawił po sobie prawie gotową - stanowiącą pokłosie wspomnianego apelu - edycję „prac umysłowych”. Jego przyjaciel - August Bielowski ujawnił niezwykle wzruszające kulisy redagowania tegoż materiału:

\section{Długą chorobą i ustawicznym natężaniem umysłu znacznie już był [Józef Borkowski - T. P.] zwątlony na siłach, kiedy w skutek podanej}

1 J. Dunin Borkowski, [inc.: „Pisarze nasi chcąc ze swojej strony przyczynić się do wsparcia pogorzelców galicyjskich...”], „Dziennik Mód Paryskich”1842, nr 16, s. 128.

2 Rzeszów spalił się w nocy z 26 na 27 czerwca 1842 r. Większość zabudowy miasta była w tym czasie drewniana, a kilkudniowy brak opadów deszczu przyczynił się do rozprzestrzeniania płomieni w błyskawicznym tempie. Mieszkańcy nie mieli czasu na ratowanie mienia. W wyniku pożaru kilka osób straciło życie, a ok. 3 tys. zostało bez dachu nad głową. Należy nadmienić, że 19 lat później, w 1861 r. Rzeszów liczył około 8 tys. mieszkańców. Zatem można przypuszczać, że niemal połowa obywateli miasta nie miała gdzie mieszkać po wspomnianym pożarze. Spaliły się nie tylko domy mieszkalne, ale także miejsca pracy np. zakłady rzemieślnicze. Wielu rzeszowian w ciągu jednej nocy zostało bez dachu nad głową, żywności, odzieży i źródła utrzymania. Informacji o tragicznym w skutkach pożarze dostarcza odezwa nr 9745 c.k. Radcy Gubernialnego i Starosty Cyrkularnego Tadeusza Lederera, skierowana do obywateli Rzeszowa w sprawie pomocy ofiarom pożaru, wydana 27 czerwca 1842 r. 
przez Tadeusza Wasilewskiego myśli, aby wydać Album na korzyść pogorzelców, podjął się powierzonej mu przez przyjaciół redakcji tej książki i w czasie, w którym słabość jego zatrważające robiła postępy, widywano go zajętego przez większą część dnia to przezieraniem i porządkowaniem nadsyłanych artykułów, to ich poprawą̧3

Pogrzeb pisarza, który odbył się we Lwowie 20 czerwca I843 roku, w konwencji staropolskiego theatrum funebris, zgromadził tłumy żałobników ${ }^{4}$. Niestety, pamięć o autorze Sonetów pettewnych nie przetrwała próby czasu. Dopiero w wieku XX ten „niesłusznie zapomniany poeta” zaczął powoli, na nowo zajmować kolejne pokolenia badaczy polskiego romantyzmu ${ }^{6}$.

Po przedwczesnej śmierci Józefa Dunina Borkowskiego doszło do wyczerpania spoistości ideowej, powstałej w opozycji do pisarstwa Alberta Miera i Wincentego Kopystyńskiego, naukowo zorganizowanej grupy poetyckiej Ziewończyków ${ }^{7}$, którzy - ze względu na cenzurę - z romantycznego kultu przeszłości zamierzali uczynić ideologiczne narzędzie łączenia wspólnoty zniewolonej Europy ${ }^{8}$.

3 A. Bielowski, Żywot Józefa hrabiego Dunina Borkowskiego, w: Album na korzyść pogorzelców. Wydane przez Józefa Dunina Borkowskiego, Lwów 1844, s. 342-343. W cytatach zachowano oryginalną pisownię, zmodernizowano natomiast interpunkcję, aby prezentowane fragmenty uczynić bardziej zrozumiałymi.

4 Opis uroczystości zamieściła „Gazeta Lwowska”: „Tutejsi literaci, artyści, księgarze oraz bardzo liczne grono przyjaciół znajomych towarzyszyło dnia 20 b.m. zwłokom na cmentarz łyczakowski do grobów familijnych. Karawan sześciosprzężny postępował za trumną, którą dźwigano na barkach od domu zmarłego aż do miejsca wiecznego spoczynku. Wszystkie stany i księża, obywatele, młodzież uniwersytetu, mieszczanie ubiegali się, aby choć przez chwilę ten drogi im ciężar spoczywał na ich ramionach. Wzruszająca była scena, gdy kmiecie $\mathrm{z}$ dóbr zmarłego przed samym progiem wieczności domagali się, aby im wolno było znieść do grobu ciało na swych barkach. I tak obywatele zmieszani z kmiotkami złożyli trumnę w kaplicy familijnej, którą wszyscy niemal obecni opuścili z pamiątką pogrzebową: kilką złotymi nitkami frędzli, z których ręka przyjaciół trumnę obnażyła $\mathrm{z}$ niewymownym żalem i z tym uczuciem w sercu” (,Gazeta Lwowska”1843, nr 72, s. 477).

5 M. Jasińska, Niestusznie zapomniany poeta-Józef Dunin Borkowski. (Próba charakterystyki twórczości), „Prace Polonistyczne” 1951, t. 9, s. 214.

6 Zob. B. Kurzeja, Dziewiętnastowieczny Lwów i jego mieszkańcy w krzywym zwierciadle - na podstawie „Sonetów pettewnych” Józefa Dunina Borkowskiego, „Jednak Książki. Gdańskie Czasopismo Humanistyczne" 2014, nr 1, s. 37-49.

7 Zob. K. Poklewska, W kręgu „Ziewonii” i „Dziennika Mód Paryskich”. (Z dziejórw grup literackich w Galicji lat 1830-1848), „Zeszyty Naukowe Uniwersytetu Eódzkiego. Nauki Humanistyczno-Społeczne" 1962, z. 25; M. Ruszczyńska, Ziewonia. Romantyczna grupa literacka, Zielona Góra 2002.

8 Dopiero w okresie wolności 1848 r. pisano, że kolejna szansa na odrodzenie przedrozbiorowej Rzeczypospolitej została zmarnowana z powodu naszej naiwnej idei „słowiańskiej” renowacji despo- 
Stawiając na rozwój umysłowy, moralny i estetyczny, pisarze galicyjscy nawiązywali do starogreckiego modelu kultury obywatelskiej - kalokagatii. W ramach „związku literackiego, który powstał pomiędzy szkolną młodzieżą galicyjską", Józef Dunin Borkowski zamierzał rekonstruować kulturowe posłannictwo greckich „córek Mnemozyne” potrafiących - jak pisze Teresa Kostkiewiczowa - „sobie właściwymi środkami i sposobami reprezentować oraz utrwalać obrazy przeszłości, przekazywać je późniejszym wiekom, inspirując refleksję o przemijaniu” ${ }^{\circ}$. August Bielowski uznawał go za wyją̧tkową osobowość, jakże odmienną od arystokratycznej młodzieży bawiącej się w salonach Lwowa:

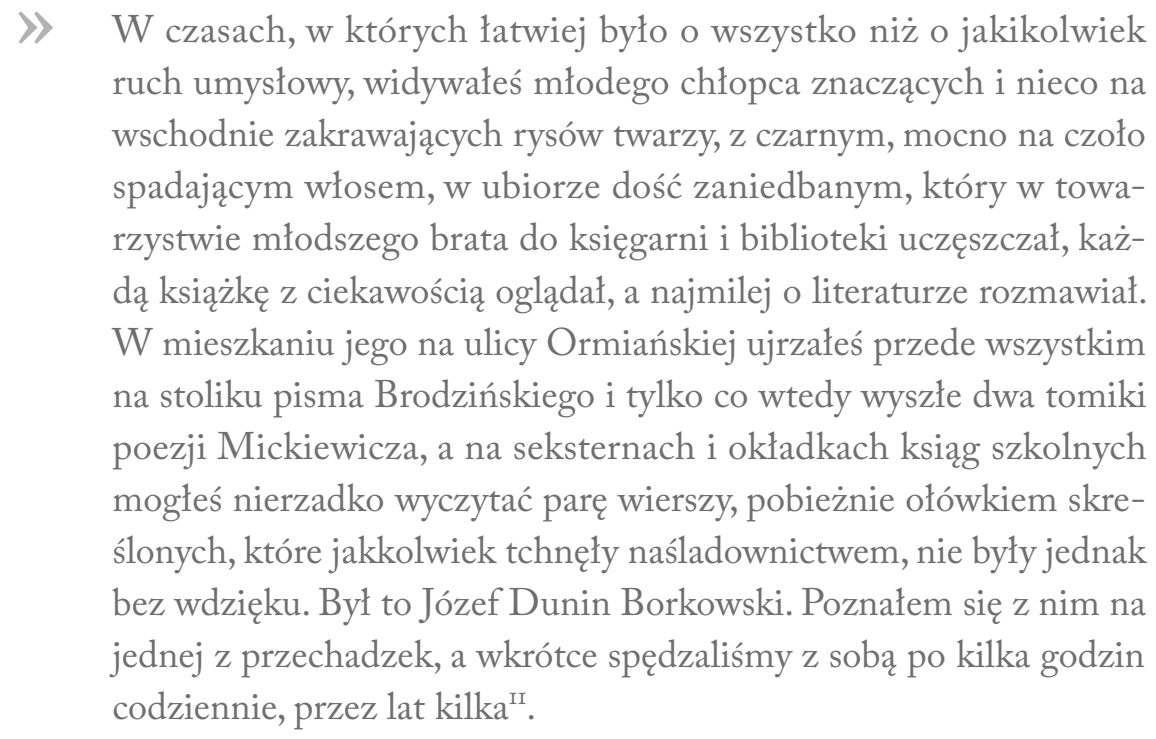

Nieznaną w Galicji modę na czytelnictwo polskiej literatury Borkowski zawdzięczał edukacji u Samuela Bogumiła Lindego. W „Tygodniku Literackim” czytamy, że „wychowany w szkołach warszawskich, opuściwszy je dopiero za rekwizycją rządu austriackiego, przywiózł ze sobą [do Lwowa - T. P.] jak towar zagraniczny znajomość języka polskiego, poważanie piśmiennictwa, wiadomość o autorach i dziełach polskich, gdzieś tam wychodzących i wcale odrębne o nich

tyzmu, co zostało wykorzystane przez „hersztów moralnych, archierejów świętojurskich, twórców austriacko-moskiewsko-ruskiej narodowości [...] szczwano ich infułami, konferencjami tajnymi, okólnikami rządowymi przeciw «zagwarantowanej» konstytucją narodowości polskiej” ([b.a.], Pierwszy akt, „Dziennik Mód Paryskich” 1848, nr 24, s. 189).

9 M. Grabowski, Pamiętniki o literaturze polskiej między 1830 a 1848. Literatura galicyjska, „Dziennik Warszawski” 1851, nr 101, s. 2.

10 T. Kostkiewiczowa, Mnemozyne i córki. Pamięć w literaturze polskiej drugiej potowy XVIII wieku, Toruń 2019, s. 9.

11 A. Bielowski, Żywot Józefa hrabiego Dunina Borkowskiego, s. 331. 
pojęcia, jakimi wpływał na początkujące talenty"'22. Powrót do Galicji i nauka w lwowskim gimnazjum ułatwiły upowszechnianie przywiezionych przez niego materiałów, zwłaszcza - jak podawał jego brat Aleksander Borkowski - dotyczących „wiadomości o pisarzach polskich i literaturze polskiej, o czym my w Galicji nie mieliśmy wyobrażenia" ${ }^{2}$. Późniejsza edukacja w Czerniowcach ${ }^{\mathrm{I}}{ }^{\text {sprawiła, że }}$ "Józef, który miał nadzwyczajną łatwość w przyswajaniu sobie obcych języków, wziął się zaraz do nauki greckiego" ${ }^{5}$. Te kontakty utwierdziły pisarza w przekonaniu o duchowym charakterze procesu dziejowego i określiły jego system aksjologiczny, dla którego najwyższą wartością było przekonanie o „wolności jako celu dziejów oraz o postępującej samowiedzy wolności jako sposobie rozwoju ludzkiego ducha"'

W okresie polistopadowym grono młodych pasjonatów zajmujących się literaturą we Lwowie powiększyło się dość znacznie, a przyjacielskie spotkania inspirowane przez „Borkowskiego przybrały postać uczonych posiedzeń, na których każdy płody swoje odczytywał i zdania drugich zasięgał"17. Rekonstruowali oni w swych dziełach mit dawnej wspólnoty. Jeden z uczestników tychże spotkań - Kazimierz Władysław Wójcicki wspominał:

\section{Bielowski miał właśnie ukończony wzorowy swój przekład poematu: Wyprawy Igora; Siemieński: Rękopisu Królodworskiego; Józef Borkowski pracował nad literaturą nowo-grecką; Leszek napisał z podań ludu śliczną powieść swą: Orty z Herburtórw; Siemieński znakomity rapsod:}

12 Uwagi ogólne nad literaturq w Galicji. (Dokończenie), „Tygodnik Literacki” 1842, nr 52, s. 416.

13 Leszka hr. Dunina Borkowskiego autobiografia, „Dziennik Polski” 1897, nr 133, s. 1. Należy w tym miejscu wyjaśnić, że brat Józefa używał kilku imion; początkowo Aleksander, później Aleksander Lubomir, a w okresie współpracy z „Dziennikiem Mód Paryskich” podpisywał swe recenzje inicjałami L.D.-B. Imię Leszek poeta eksponowal natomiast po napisaniu pod wpływem Dziadów cz. III - Wieszczeń Lechowych, które Bóg dat, aby ogtosit ludowi (1835). W tym artykule będziemy posługiwać się imieniem Aleksander (w bibliografii i przypisach pozostawiając oczywiście zapis zgodny z pierwotnymi publikacjami).

14 Obydwaj bracia przez rok studiowali filozofię w środowisku greckich uchodźców w Czerniowcach. W czasie gdy Grecja walczyła o niepodległość, prowincjonalne miasteczko przyłączonej do Galicji Bukowiny zapewniało schronienie emigrantom. Z Gródka (koło Zaleszczyk) - skąd pochodzili bracia Borkowscy - do Czerniowiec jest bliżej (około $70 \mathrm{~km}$ ) niż do Lwowa. Pierwszy rok studiów w tym czasie był kursem filozoficznym i być może tak postanowili przygotować się do jego zaliczenia. Edukacja w Czerniowcach miała istotny wpływ na ich znajomość kultury greckiej i greki. W okresie tym Aleksander Borkowski tworzył inspirowaną Odprawa postów greckich tragedię o wojnie Wenecji z Turcją. (Zob. T. Półchłopek, Leszka Dunina Borkowskiego dyskurs o wolności w tragedii „Arnalda de Rocas, czyli zdobycie Nikozji”, „Prace Polonistyczne” 2016, ser. LXXI, s. 121-138).

15 Leszka hr. Dunina Borkowskiego autobiografia..., s. 1.

16 M. Janion, Artysta romantyczny wobec narodowego sacrum, w: eadem, Czas formy otwartej: tematy i media romantyczne, Warszawa 1984, s. 82-83.

17 A. Bielowski, Żywot Józefa hrabiego Dunina Borkowskiego..., s. 332. 


\section{Traby w Dnieprze; Magnuszewski fragment historyczny: Wotoszczyzna, poemat dramatyczny: Mtodzieniec, wiersze drobniejsze i prozą powie- ści: Guy-du Faur, czyli Pacta Conventa i Zemsta panny Urszuli, z czasów Zygmunta III. Wszystkie te utwory, będące wówczas w rękopisie, odczytywaliśmy w naszym kółkư ${ }^{\mathrm{I} 8}$.}

Józef Dunin Borkowski w tym okresie przekładał Bogów greckich Friedricha Schillera, „badał język i historię mołdawską w związku z dziejami polskimi i posyłał do dziennika mołdawskiego w Jassach wiadomości o literaturze polskiej. W końcu zajął się zbadaniem wpływu, jaki wywierała od najdawniejszych czasów literatura

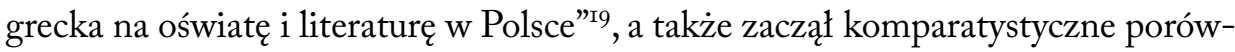
nania, „ile z niej u nas korzystano”20. To dojrzewanie do samodzielnego ujmowania ducha czasu redefiniowało strategię podziału na zwolenników Mickiewiczowskich „prawd żywych” i „prawd martwych”, dlatego dawny propagator romantyczności - Borkowski w cyklu Sonetów pettewnych rozprawił się z „poetyką zachwytu” wieszcza $^{2 \mathrm{I}}$. Trudno jednoznacznie określić, na ile takie nawiązanie do kanonu przedlistopadowego wynikało z pragnienia porzucenia młodzieńczych fascynacji, a na ile ze zredefiniowania kulturowej wspólnoty.

Konieczność przesyłania „Prac Literackich” przez Józefa Dunina Borkowskiego do Wiednia, gdzie cenzura była mniej ostra ${ }^{22}$, natchnęła pisarza ideą stworzenia we Lwowie periodyku, który pod z pozoru błahą formą upowszechniania mód, przemycałby niewygodne dla władzy treści ${ }^{23}$. W ten sposób powstał „Dziennik Mód Paryskich”, ograniczający się początkowo do promowania wspomnianej idei kalokagatii „lekkimi” recenzjami z koncertów i przedstawień teatralnych, zdawkowej kroniki literackiej i muzycznej oraz przedstawianiem „niezaangażowanych” tekstów

18 K.W.Wójcicki, Wspomnienie o Józefie Dzierzkowskim, „Tygodnik Ilustrowany” 1865, nr 284, s. 78.

19 H. B., Józef Borkowski (1809-1843), w: Ztota przędza poetów i prozaików polskich, red. P. Chmielowski, t. 2, Warszawa 1885, s. 745-746.

20 A. Bielowski, Żywot Józefa Dunina Borkowskiego..., s. 340.

21 K. Walicka, Józef Dunin Borkowski i jego poetycka twórczość. (Wobec nowego wydania A. Ważyka), „Prace Polonistyczne" 1952, seria X, s. 207.

22 Zob. Prace literackie, t. 1, wyd. J. hr. Dunin-Borkowski, Wiedeń 1838.

23 Karol Estreicher pisał: „O całych dziewięciu latach «Dziennika Mód» powtarzam zdanie, że pod względem nauk ścisłych, pod względem filozofii, historii, bio- i bibliografii, niczym się nie przysłużył krajowi, nic tam ważnego w nim nie ma. Wartość atoli dziennika pod względem poezji i powieści, pod względem ducha i tendencji wyłamującej się spod przewagi obczyzny i idącej na przebój przeszkodom, jest ogromna: dziennikowi bowiem temu zawdzięczamy, że możemy dzisiaj pochlubić się kilku pisarzami niepoślednio występującymi w piśmiennictwie. Dzisiaj podobny dziennik nie uzyskałby powodzeń, bo wymagalności są inne, bo lekka beletrystyczność nie wystarczy na pokarm; bo dzisiaj obok zabawy, nauka winna iść w parze" (K. Estreicher, Dziennikarstwo w Galicji i Krakowie. Do roku 1860 , „Biblioteka Warszawska” 1861 , t. 2, z. 4, s. 422-423). 
poetyckich ${ }^{24} . Z$ czasem dopiero pojawiły się w nim polemiki $z$ „pisarzami, którzy ani stylem, ani działalnością prawą zalecić się nie mogli” ${ }^{25}$.

\section{II}

Współtowarzyszem literackich przedsięwzięć Józefa Dunina Borkowskiego był, jak już wspominaliśmy, jego młodszy brat - Aleksander oraz wychowanek bazylianów z Buczacza - August Bielowski, który - ze względu na pochodzenie - doskonale rozumiał złożoność koncepcji historiozoficznej swego przyjaciela. Aleksander uznał, że musi dokończyć rozpoczętą przez brata pracę około wydania nadesłanych materiałów, i na łamach „Dziennika Mód Paryskich” pisał:

mam zarazem obowiązek uwiadomić publiczność, że zapowiedziane przez nieboszczyka Album na korzyść pogorzelców rzeszowskich, w rękopisach całkiem zebrane i ułożone, a w wielkiej części już wydrukowane, którego wyjście opóźniła dotychczas długa i uciążliwa choroba opłakiwanego wydawcy, najdalej do trzech miesięcy zupełnie gotowym i rozdanym zostanie. Spis prenumeratorów zastałem w porządku, a dokańczając wydanie, starać się będę zachować we wszystkim znamiona i układ, jakie chciał nadać tej książce świętej pamięci nieodżałowany brat mój $j^{26}$.

Obaj wymienieni pisarze (August Bielowski i Aleksander Borkowski) stworzyli funeralny Dodatek do Albumu na korzyśc pogorzelców, stylizując swoje teksty na wspomnienia w formie dramatycznego dyskursu o niespodziewanej śmierci wodza, który pozostawił niedokończone dzieło całego życia. Ziewończycy uważali Józefa Dunina Borkowskiego za duchowego przywódcę przyjaźni ludów upadłej Rzeczypospolitej z „narodem greckim i mołdawskim” ${ }^{27}$. Taka idea tworzyła kulturową antynomię dla despotycznego centrum, które popierało panslawizm i austriackie słowianofilstwo. Leszek Dunin Borkowski pisał w owym Dodatku:

24 Zob. J. Rosnowska, Twórcy „Dziennika Mód Paryskich”, „Rocznik Historii Czasopiśmiennictwa Polskiego" 1967 , nr 6/2, s. 70 .

25 K. Estreicher, Dziennikarstwo w Galicji i Krakowie..., s. 421.

26 L. Dunin Borkowski, [inc.: „Osiemnastego zeszłego miesiąca dotknął mnie cios najboleśniejszy...”], „Dziennik Mód Paryskich”1843, nr 14, s. 112.

27 Idem, Dodatek, w: Album na korzyść pogorzelców..., s. 323. Interesujący nas Dodatek obejmował kolejno: kilkustronicowy wstęp autorstwa Aleksandra Dunina Borkowskiego (s. 321-325), Żywot Józefa Dunina-Borkowskiego napisany przez Augusta Bielowskiego (s. 327-344) oraz dedykowaną Józefowi przez brata Aleksandra funeralną elegię pt. Jego cieniom (s. 345-351). 
\Jeżeli pomiędzy duchami narodów można zawiązać jak między szczególnymi ludźmi węzeł przyjazny, któryby wzniecał i żywił wzajemne poważanie ich umysłowości, utrzymując ciągłe zajęcie i ciekawość dla jej płodów: to pośrednikiem takim pomiędzy nami a narodami greckim i mołdawskim był niezaprzeczenie śp. wydawca. [...] Imię jego było u tych narodów znanym powszechnie, wspominali go w rozmowach i pismach swoich $\mathrm{z}$ uniesieniem jako jedynego polskiego hellenistę. Wszyscy podróżni greccy i wołoscy, uczeni i nieuczeni, znajomi i nieznajomi przejeżdżając przez Lwów, wstępowali najprzód do niego. Ktokolwiek z tamtych stron nadjeżdżał, przywoził z sobą listy zalecające, pisma czasowe, książki i rękopisy nawet młodych, poczynających pisarzy. Gdziekolwiek wychodziła książka grecka lub mołdawska, przysyłano mu ją w upominku, bo uczeni tych narodów uważali go jako jedyny organ mający ich w czasie do nas zbliżyć, z nami zapoznać i zaprzyjaźniće ${ }^{28}$.

August Bielowski ponadto, pod pretekstem przedstawienia życiorysu przyjaciela, zaprezentował swój krytyczny stosunek do politycznych doktryn, które, obiecując wolność Słowian, poszerzały władzę zaborców. Dlatego też korzeni cywilizacji słowiańskiej galicyjscy twórcy szukali w starożytnych Indiach, co było efektem ich kontaktu z europejskimi ośrodkami naukowymi ${ }^{29}$. To właśnie w Albumie na korzyść pogorzelców przyjacielowi zmarłego pisarza udało się przemycić myśl, że Józef Borkowski pomysł

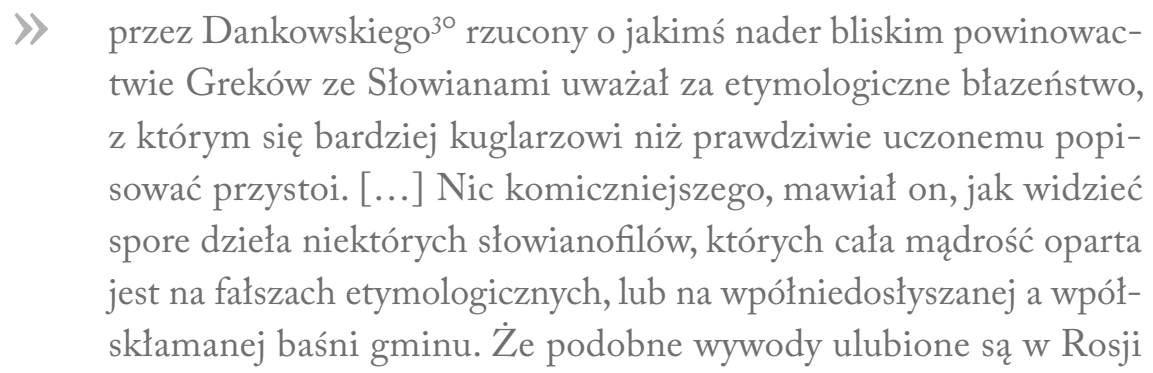

28 Ibidem.

29 Leszek Dunin Borkowski po zakończeniu powstania studiował sanskryt w Królewcu i poznał najważniejsze odkrycia uczonych angielskich i niemieckich. Efektem tego był cykl artykułów $O$ najdawniejszych zabytkach pisemnych („Pamiętnik Literacki” 1850, nr 14, s. 313-323; nr 15, s. 337-375; nr 16, s. 361-375; nr 17, s. 385-396; nr 18, s. 409-420; nr 19, s. 433-447; nr 20, s. 465-469).

30 Alois Gregor Dankovský - słowacki uczony, o którego koncepcji wspomina Joanna Nowak w książce pt. Piastuni dziejów. Wizerunki narodów europejskich w polskiej refleksji romantycznej (Warszawa 2018, s. 288). 
i powtarzane od niektórych pisarzy jak Bodiańskiego ${ }^{3 \mathrm{I}} \mathrm{i}$ innych, jest tego inna przyczyna ${ }^{32}$.

Ziewończycy, jak żadna inna grupa poetycka, doświadczyli konfliktu cywilizacyjnego o ziemie ruskie Rzeczypospolitej. August Bielowski, za Józefem Borkowskim, powtarzał, że tylko przyjaźń narodów zniewolonych przez despotyzm jest w stanie uchronić ich przed narzuceniem im kultury zaborcy. Miały im w tym szczególnie pomóc ideał greckiej demokracji i wychowawcza rola sztuki. Ten polityczny testament zmarły przedwcześnie pisarz przekazał Bielowskiemu w trakcie licznych „poufnych rozmów”33, które ze sobą odbyli.

\section{III}

Leszek Borkowski bardzo przeżywał śmierć brata ${ }^{34}$, dlatego informując o jego odejściu, wyznał: „dotknął mnie cios najboleśniejszy, jaki kiedykolwiek mógł dotknąć. Odtąd już nie masz dla mnie nieszczęścia”35. Napisana przez niego i zamykająca Dodatek do Albumu na rzecz pogorzelców elegia Jego cieniom jest - w przekonaniu Władysława Zawadzkiego - przykładem arcydzieła poezji funeralnej:

wiersze jego pomniejsze, rozrzucone po czasopismach, nie odznaczały
się oryginalnością polotu ani uczuciem, były to raczej, że porównania
tego użyję, misternie z marmuru rzeźbione utwory, w których prze-
błyskiwała nieraz myśl świetna, ale owiana chłodem, albo tryskająca
sarkazmem. Raz tylko uczucie wzięło górę i wylało się pieśnią pełną
tkliwości, która jest najpiękniejszą ze wszystkich jego poezji, a to,
gdy tknięty do głębi duszy śmiercią brata Józefa napisał na śmierć
jego elegię pod tytułem: Jego cieniom. Trudno istotnie na polu po-
ezji znaleźć coś piękniejszego, jak ta pieśń żalu, rwąca się z duszy
najrzewniejszymi tonami. Poeta, błąkając się za cieniem zmarłego,

31 Osip Maksimowicz Bodianski był badaczem folkloru i odkrywcą tłumaczonych na grecki romansów rycerskich.

32 A. Bielowski, Żywot Józefa hrabiego Dunina Borkowskiego, s. 338-339.

33 Ibidem, s. 340.

34 Obawy o zdrowie chorego na gruźlicę brata towarzyszyły mu od dawna. Na rok przed jego śmiercią w notatkach osobistych zapisał: „W nocy 19 na 20 juli[i] 1842 śniło mi się w Paryżu, że Józef umarl, a potem, że go zobaczyłem bardzo słabego i wycieńczonego" (Rękopisy Aleksandra (Leszka) Borkowskiego zwiqzane z dziatalnościa literacka, publicystycznq i naukowa, rkps Ossol. 13115/ III, s. 249).

35 L. Dunin Borkowski, [notatka bez tytułu], „Dziennik Mód Paryskich” 1843, nr 14, s. 112. 
aby go dosięgnąć pożegnania pieśnią, śle mu w zagrobowe światy pozdrowienie wszystkimi głosami morza i ziemi, wszystkimi barwami i dźwiękami przyrody ${ }^{36}$.

Elegia Jego cieniom w perspektywie całej twórczości Aleksandra (Leszka) Dunina Borkowskiego to niezwykła antynomia i manifestacja ograniczonych zdolności epistemologicznych człowieka. Zbudowana $\mathrm{z}$ czternastu numerowanych oktaw została poprzedzona specyficzną formą paratekstualnego sygnału poetyki memorialnej i funeralnej:

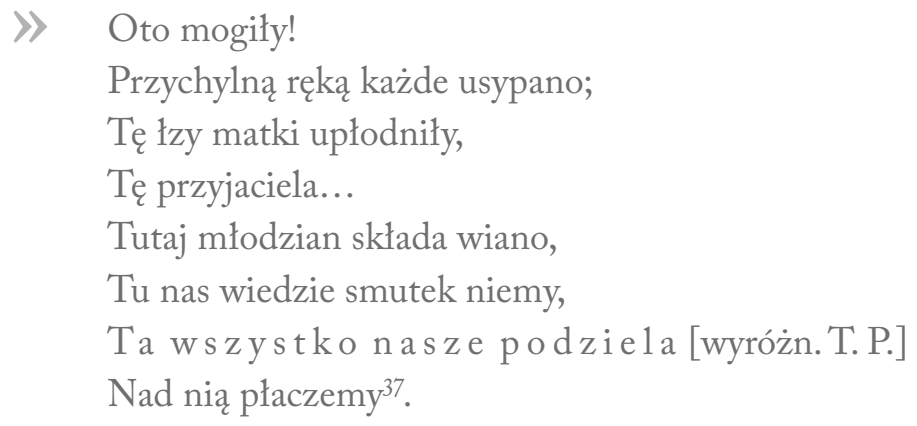

Przedostatni wers wprowadzenia wskazuje na miejsce złożenia szczątków Józefa Dunina Borkowskiego. Otóż szambelan Stanisława Poniatowskiego - Wincenty Dunin Borkowski zmarłej w I8I2 roku żonie wybudował na Cmentarzu Łyczakowskim kaplicę w kształcie greckiej świątyni, ozdobionej czterema kolumnami korynckimi, z dwiema rzeźbami i łodzią Charona na dachu. Było to pierwsze tego typu funeralium znajdujące się poza murami miasta. To właśnie tam pochowano zmarłego młodo pisarza, a z czasem przed kaplicą pojawiały się kolejne „przychylną ręką usypane” groby, tworząc niezwykłą nekropolię.

Już pierwsza oktawa interesującego nas wiersza manifestuje filozoficzną bezsilność poety, który z tajników mądrości poznawanej wśród Greków w Czerniowcach, a później z - fascynującej europejskich uczonych - zasad filozofii wedyjskiej uczynił jedną ze swych najważniejszych idei dyskursu o patologiach kultury europejskiej.

Dla XIX-wiecznego czytelnika elegii pojawiająca się w niej stylistyczna matryca rzymska była dość jasna - wiersz wykorzystywał schemat klasycznej mowy, zbudowanej według zasad sztuki retorycznej oraz mechanizm gradacji rozpaczy. Pierwszą oktawę inicjują pytania przynależne do tego etapu żałoby, kiedy to opłakujące utra- 
conego bliskiego osoby pozwalają się zdominować przez emocje ${ }^{38}$. Poszczególne wersy emanują przy tym ogromem braterskiej miłości:

\section{\ Pytałem braci, przyjaciół pytał \\ Gdzieś się zapodział? Czemu cię nie ma? \\ Dawnom uściskiem, słowem nie witał \\ Objęciami i oczyma. \\ Gdziekolwiek jesteś, daleki, bliski, Ziemi otchłanie, niebios sklepienie \\ Czy noc cię kryje, czy gwiazd połyski, Pozdrowienie! pozdrowienie! ${ }^{39}$}

W kolejnych strofach ujawniają się wątpliwości natury epistemologicznej - brak bezpośrednich „kanałów komunikacyjnych” między poetą żywym i umarłym powoduje, że Aleksander Dunin Borkowski, który nie wyrzekł się przeświadczenia o duchowym charakterze świata, pragnie nawiązać łączność z jakkolwiek rozumianym „zaświatem”. Jest przy tym przekonany, że ten - opiewany przez poetów od czasów biblijnego psalmisty, Dawida - świat widzialny umożliwia kontakt $\mathrm{z}$ duchem zmarłego. Romantyczne przekonanie, że zmarły istnieje „obok”, ale nie przekażemy mu bezpośrednio swego „czucia” jest wprawdzie dramatem żyjącego, ale za wszelką cenę poszukuje on innych, pośrednich sposobów komunikacji. Dlatego w oktawach od drugiej do czwartej aż dziesięć wersów rozpoczyna wyrażenie zainicjowane przyimkiem „przez”, sygnalizującym alternatywne możliwości mistycznego kontaktu z nieżyjącym bratem. Każdą ze strof kończy emocjonalna formuła powiadamiająca o celu prowadzonej lirycznej narracji - „Pozdrowienie! pozdrowienie!”:

\section{》Przez świeżość ranku, jutrzenki bladość, \\ Co ze snu budzi, życiem przenika; \\ Przez gwary świtu, przez gajów radość, \\ Przez ponocną pieśń słowika, \\ Przez pośpiech wiatrów, obłoków chyżość, \\ Przez rzeźwość rosy, słońca promienie, \\ Sadów zieloność, wonność i świeżość \\ Pozdrowienie! pozdrowienie! $4^{\circ}$}

38 Zob. J. Pypłacz, Pię́ stadiów żatoby w „Odzie” I.24 Horacego, „Biuletyn Biblioteki Jagiellońskiej” 2016, R. LXVI, s. 219.

39 L. Dunin Borkowski, Jego cieniom, s. 347.

40 Ibidem. 
Wyłaniające się ze wspomnianych strof poetyckie obrazy natury: „świeżość ranku”, ,jutrzenki bladość”, „gwary świtu”, „gajów radość”, „pieśń słowika”, „pośpiech wiatrów”, „obłoków chyżość”, „rzeźwość rosy”, „słońca promienie”, „sadów zieloność, wonność i świeżość” (strofa druga), „mgły wieczorne”, „tęskność księżyca”, „blask łyskawic”, „piorunów grzmoty”, „wiatrów wycia”, „burz łoskoty” (strofa trzecia), ,gwar murawy”, „drzew szmer cichy”, „sploty wieńców” (strofa czwarta), odzwierciedlają wspólnotę doświadczeń piszącego i żegnanego przezeń zmarłego brata. Poeta ma nadzieję, że wszystkie te „kanały komunikacji” „przerwą grobów milczenie” i umożliwią mistyczny dialog między żywymi a umarłymi:

\section{1) Przez gwar murawy i drzew szmer cichy, \\ Przez sploty wieńców, co ciągle wonią \\ Smutne ku ziemi chyląc kielichy \\ Przyjazną sadzone dłonią, \\ Skrapiane łzami wiernej dziewczyny, \\ By przerywały grobów milczenie [wyróżn. T.P.], Szepcząc umarłym ziemskie nowiny $[\ldots]^{4 \mathrm{I}}$}

Przywoływanego już przez nas Władysława Zawadzkiego najbardziej zachwyciła oktawa piąta, która przypominała mu polistopadowe zebrania u Kazimierza Władysława Wójcickiego lub u adwokata - Augusta Wysockiego, na których młodzi poeci - o czym była mowa - czytali własne utwory i uzgadniali zawartość redagowanych przez Bielowskiego tomów „Ziewonii” oraz „Prac Literackich”. Aleksander Borkowski zwraca jednak uwagę, że śmierć Józefa pozbawiła tę grupę literacką zasadniczego filaru:

\section{\ Otośmy siedli w śpiewaków gronie, \\ Aby spólne zawieść piosenki, \\ Jednej nam struny brakło w bardonie, \\ Jednego serca i ręki. \\ Przez wszystkich piewców na naszej ziemi, \\ Każdy dech piersi, każde strun drżenie, \\ Gra mi wszystkiemi, pieśni wszystkiemi - \\ Pozdrowienie! pozdrowienie! $4^{42}$}

41 Ibidem, s. 348.

42 Cyt. za: W. Zawadzki, Leszek Dunin Borkowski, s. 178. Ze względów cenzuralnych drugi wers został zmieniony, u Borkowskiego jest: „By narodowe zawieść piosenki” (Jego cieniom, s. 348). 
Śmierć brata uznał on za swoiste memento i wezwanie „do pilności i pośpiechu młodych literatów mających zwykle tyle do zwalczania przeszkód, tyle do przełamania trudów i zrażeń, a żadnej znikąd zachęty”33. Był bowiem przekonany, że ,jeśli nie mamy odbiec uprawianej przez nas roli narodowej oświaty rokującej z czasem żniwo pomyślne, to zachęta jest nam potrzebna" ${ }^{4}$.

Główną część prezentowanego wiersza stanowią strofy szósta i siódma, w których - wbrew sprzecznościom sygnalizowanym w początkowych pytaniach retorycznych - została wyartykułowana charakterystyczna dla romantyków wiara, że poezja przenosi wieszcza w przestrzeń boską. Oto ten, który wcześniej był wysłannikiem Boga do ludzi, teraz na powrót „śpiewa bóstwu w świętych podwojach”:

\section{\ Przez pełne życia, pełne miłości, Wdzięków i mocy, barwy i głosów \\ Duchy olbrzymy wieszczów przeszłości \\ Silniejsze od śmierci ciosów, Z którymi teraz w jednychże zdrojach \\ Natchnionej piersi gasisz pragnienie, Śpiewając bóstwu w świętych podwojach... Pozdrowienie! pozdrowienie! 45}

Tak więc poeta - wbrew greckiej tradycji sporu z przeznaczeniem - wraca do swojego miejsca narodzin, jego ziemski pobyt był posłannictwem do ludzi, śmierć jest odwróceniem tej misji. Podobny motyw pojawia się też w nieopublikowanej recenzji powieści Józefa Ignacego Kraszewskiego Poeta i świat, w której Aleksander Borkowski pisał, że twórca ma za zadanie odkrywać wyroki boskie:
1) Mędrzec i nauczyciel, kapłan i prawodawca, rządca i sędzia, i lekarz, i doradca, i pocieszyciel, istny posłaniec boży do swego narodu. Iskra bożego natchnienia była mu listem wierzytelnym, a utwory jego w postaciach rozlicznych, czy to rozbudzając sławę uśpioną w czy- nach minionych, czy rozpalając do nowych działań i przedsięwzięć, czy zwalczając nieprzyjaciela ludzkości: pierwiastek złego, ciemnotę, obejmujące przeszłość, teraźniejszość i przyszłość, ze wszystkimi ich zjawiskami, były sprawieniem poselstwa ${ }^{46}$.

43 L. Dunin Borkowski, Dodatek, w: Album na korzyść pogorzelców..., s. 324.

44 Ibidem.

45 Ibidem, s. 348-349.

46 Rkps Ossol. 13115/III, s. 46-47. 
Siódma, centralna oktawa Jego cieniom znów jest retrospekcją ziemskiej egzystencji zmarłego. Pojawia się w niej motyw greckiego powstańca - palikara zagrzewanego do czynu poezją tyrtejską, zdolną przechować pamięć o niezwykłych czynach z przeszłości. Stanowi to niejako preludium do strofy ósmej, w której następuje swoiste uspokojenie i pogodzenie się z fatalizmem losów człowieka. Sztuka literacka mająca spełniać cywilizacyjną rolę tworzenia wspólnoty kulturowej, wskutek śmierci jej głównego przewodnika, zatraciła niestety tę zdolność. W przypadku Aleksandra Dunina Borkowskiego taka koncepcja rozwoju cywilizacji nie była tylko romantycznym mitem, ale zrealizowaną w praktyce próbą oddziaływania wychowawczego sztuki. Po kolejnym etapie konfliktu narodowościowego pisarz zaproponował i zrealizował we Lwowie program powołania Towarzystwa Przyjaciół Sztuk Pięknych, konstatując:

\section{》 Cnoty obywatelskie, uczucie miłości, szlachetność popędów - to wszystko łączy się jak w jednym ognisku w uczuciu piękna, którego uroczym kwiatem jest sztuka. Rozbudzać więc zamiłowanie do sztuki nie jest prostym dogadzaniem amatorstwu niewielu, lecz jedną z waż- nych sprężyn postępu, która podnoszeniem cnót w społeczeństwie wiedzie je ku lepszej przyszłości, która zarówno z literaturą strzeże skarbów jego tradycji, uczy je miłować rodzinną ziemię, nakazuje oddawać cześć wszystkiemu, co piękne, dobre i wielkie ${ }^{47}$.}

W myśl idei, że „sztuki piękne są częścią uzupełniającą oświatę" ${ }^{48}$, w omawianej strofie ósmej dokonuje się racjonalne pożegnanie $\mathrm{z}$ wieszczą muzą, która wraz ze zmarłym poetą została pozbawiona zdolności twórczej:

\section{\} \text { Oto mieliśmy wieńce gotowe, } \\ By zasłużone ozdabiać skronie, \\ Wtem zaszumiały pieśni grobowe; \\ Milkną usta, słabną dłonie. \\ Skoro zagasły u życia brzegów \\ Żarów młodości czyste płomienie; \\ $\mathrm{Z}$ tylu nadziei, $\mathrm{z}$ tylu zabiegów \\ Pozdrowienie! pozdrowienie! ${ }^{49}$}

47 L. Dunin Borkowski, Odezwa Dyrekcji Towarzystwa Sztuk Pięknych we Lwowie, „Dziennik Literacki i Polityczny" 1867, nr 23, s. 371.

48 Hr. L. Borkowski, O cywilizacyjnym wptywie sztuki. (Rzecz miana na zgromadzeniu Lwowskiego Towarzystwa Sztuk Pięknych dnia 10 b. m.), „Kronika Codzienna” 1876, nr 137, s. 1.

49 L. Dunin Borkowski, Jego cieniom, s. 349. 
Między strofą dziewiątą a jedenastą rozgrywa się jednak w omawianej elegii dramat poety, osamotnionego po śmierci brata. Pytania o możliwość kontaktu, nawet w perspektywie wiary w reinkarnację, nie uspokajają jego wątpliwości. Nie jest pewien, czy obrane przez niego drogi komunikacji w postaci wspomnianych wcześniej „głosów przyrody” będą w stanie dotrzeć do zmarłego i przekazać mu ziemskie wyrazy pamięci:

\section{》Gdziekolwiek jesteś z lutnią swą w dłoni \\ Zmarły za wcześnie wieszczu nasz młody! \\ Któryż cię znajdzie? który dogoni \\ Ze wszystkich głosów przyrody? \\ Który zaniesie do twego grodu \\ Przyjaciól skargi, bratnie westchnienie, \\ Płacze matczyne, żałość narodu, \\ Pozdrowienie! pozdrowienie! $!^{50}$}

Romantyczna wiara w duchowy charakter kultury, a zwłaszcza Heglowska historiozofia, pozwalała pisarzom wierzyć, że idea wypowiedziana sama zaczyna się realizować; nie umiera i jak w bajce Żegoty z Dziadów cz. III - wbrew jej wrogom - żyje i trwa. W dziesiątej strofie elegii Borkowskiego następuje załamanie przekonania o takiej transmisji i znów pojawiają się dramatyczne - odmienne od profetycznej wiary autora Wieszczeń Lechowych - zaprzeczenia, nawet własnej drogi twórczej:

\section{》 Jakie sposoby i ścieżki jakie \\ Do świata duchów z ziemi żyjących? \\ Rwąż się zupełnie związki wszelakie \\ Czym koić ranę, co krwawo sączy? \\ Zanim nastąpi wieczne złączenie, \\ Nicże nie zbliża, nic już nie łączy? \\ Pozdrowienie! pozdrowienie! \\ Serc ognistych, kochających? ${ }^{\text {I }}$}

Szukając konsolacji, poeta zamierza w jedenastej strofie ponownie nawiązać duchowy kontakt $z$ przebywającym w zaświatach bratem. Tym razem mamy tu do czynienia nie $\mathrm{z}$ konkretnymi obrazami ziemskiej przyrody, lecz z kosmolo-

50 Ibidem, s. 349-350.

51 Ibidem, s. 350. 
gicznym uniwersum, którego częścią stał się zmarły. Rozważania o pochodzeniu bytów określają topografię możliwego zjednania się dwóch pokrewnych, a jednak rozdzielonych przez zagadkę fizycznej śmierci, duchów:

\title{
》 Chwycę gęśl moją i wyślę ducha $\mathrm{W}$ promienie słońca, $\mathrm{w}$ powietrzne kraje. \\ Niech gwiazd muzyki w obłokach słucha \\ I twe głosy rozpoznaje. \\ Niech cię wyśledzi w aniołów chórze, \\ I do mej piersi znosi ich pienie. \\ Ja im za każdą wrótką powtórzę: \\ Pozdrowienie! pozdrowienie! $!^{2}$
}

Warto więc zwrócić uwagę na fenotypiczne ukształtowanie struktury utworu, w którym Horacjańskiemu modelowi pamięci przechowującej dzieła wzniosłe, poeta przeciwstawia swoistą „romantyczną racjonalność”. Przedostatnia strofa podważa przekonanie, że „pieśń ujdzie cało”. Pamięć ludzka, zgodnie z porządkiem zapamiętywania, wymaga ustawicznego przypominania, dlatego autor wiersza deklaruje:

\author{
\My nie żegnamy; i mniejsza o to, \\ Że czucia nasze, nasze nadzieje \\ $Z$ światem nieznanym, $\mathrm{z}$ cieniem istotą \\ Zimny gdzieś człowiek wyśmieje. \\ $\mathrm{Na}$ wiatr wieszamy objęcia wszędzie, \\ W grobach, miłości sadzim nasienie; \\ I jest nam życie, i śmierć nam będzie, \\ Pozdrowienie! pozdrowienie! ${ }^{53}$
}

IV

Współczesna prasa donosiła, że publiczność

\ literacka zarówno i nieliteracka powinna Album z miłym i tkliwym powitać uczuciem: jako wieniec złożony z pięknych i wonnych kwia- 
tów na rodzinnej niwie wzrosłych i w ofierze nieszczęśliwym pogorzelcom przyniesiony i jako ostatnią pamiątkę męża, który splótł ten wianek - męża, zdobnego niejedną zasługą, tak w życiu jako i domowym; jako oddającego się naukom i jako człowieka. Żalem po nim wionie ta książka i myśl czytającego z rzewnością zatrzymuje się przy ostatnich wieszcza słowach: Gdy moje oko świattem nie blyśnie - tchnących przeczuciem rychłego zgonu. Pamięć jego cnotliwym dążnościom, zasługom i chęciom życzliwego i ludzkiego serca! ${ }^{54}$

Natomiast krytyka literacka w państwie carów, kierując się ideologią panslawistyczną, pisała, że poezji w zbiorze nie ma, a wiersze

nie zwracają uwagi, owszem powszedniością i brakiem zupełnym życia, nie mówimy już natchnienia, odrażają. W tej liczbie musimy zamieścić i płody zmarłego Józefa Dunina Borkowskiego, którego Okręt [...] prócz gładkości wiersza i poprawności języka niczym się więcej nie odznacza $[\ldots]^{55}$.

Bardzo skomplikowaną operację zdezawuowania podjętej przez Józefa Borkowskiego inicjatywy wydawniczej przeprowadziła rządowa „Gazeta Lwowska”, która piórem Walentego Chłędowskiego zaapelowała o pomoc dla mieszkańców Żmigrodu koło Jasła ${ }^{56}$, a później publikowała spisy osób zaangażowanych w charytatywną pomoc dla pogorzelców ${ }^{57}$. Działania te stanowiły dość jednoznaczną próbę rozbicia lwowskiego romantyzmu. Pisarze musieli wybierać, którą inicjatywę poprzeć.

54 Anonim, Album. Pismo zbiorowe, na korzyś́ pogorzelców wydane w Wiedniu przez Józefa Dunina Borkowskiego, 1844. Wósemce większej, stron 135. Wydanie ozdobne z wizerunkiem Józefa Dunina Borkowskiego, „Przegląd Naukowy” 1844, nr 17, s. 271.

55 Album na korzyś́ pogorzelców, wydane przez Józefa Dunina Borkowskiego, z portretem wydawcy, Lwów 1844 w 8 stron 251, „Biblioteka Warszawska” 1844, t. 4, s. 220.

56 Zob. „Gazeta Lwowska”1843, nr 58, s. 379. Do pożaru Żmigrodu doszło z 17 na 18 kwietnia 1843 r. Zniszczeniu uległo wówczas całe niemalże miasto. Literaci z kręgu rządowej „Gazety Lwowskiej” - Jan Nepomucen Kamiński i Walenty Chłędowski postanowili zorganizować akcję charytatywną na wzór Albumu na korzyść pogorzelców Józefa Borkowskiego, co było oczywistą próbą przejęcia części tekstów autorów, którzy już wcześniej zadeklarowali się odpowiedzieć na, przywołany na początku tego artykułu, apel „Dziennika Mód Paryskich”. Por. A.J. Lisowski, Rozmyślania spleenisty nad 68 numerem „Gazety Lwowskiej”, „Przyjaciel Ludu” 1843, nr 8, s. 59-63.

57 Zob. Spis osób, które w biurze redakcji „Gazety Lwowskiej” przyczynity się do sktadek dla pogorzelców Żmigrodu, „Gazeta Lwowska” 1843, nr 59, s. 390; nr 62, s. 410; nr 65, s. 429; nr 68, s. 450; nr 70, s. $464 ;$ nr 73 , s. $484 ;$ nr 76 , s. $502 ;$ nr 79 , s. $522 ;$ nr 85 , s. 562 . 
》Z Zachęcony od kilku znanych naszych pisarzy do zajęcia się wydaniem Pamiętnika literackiego na korzyść pogorzelców miasta Żmigrodu, mając sobie oraz już na ten cel powierzone niektóre artykuły, upraszam niniejszym wszystkich piszących i miłośników literatury pięknej w Galicji, którzy to dobroczynne przedsięwzięcie swą pomocą zechcą wesprzeć, aby prace swe do pomienionego dziełka przeznaczone, w krótkim czasie pod adresem wydawcy do księgarni Jana Milikowskiego we Lwowie nadesłać raczyli ${ }^{8}$.

Spór o Józefa Dunina Borkowskiego spowodował, że doszło do całkowitego rozbicia integralności środowiska literackiej Galicji. W kolejnych latach, po śmierci pisarza, zaczęły powstawać teksty satyryczne dezawuujące jedność literacką programu romantycznego Lwowa. Przykładem takiego ośmieszającego utworu jest Zemsta Wandy Józefa Kalasantego Pajgerta, w którym konserwatywny antagonista podważa wartość artykułu Bielowskiego z Dodatku do Albumu na korzyść pogorzelców:

A panowie myślicie, że my literaci
Mamy tak czasu na zbyciu, jak pan marnie traci;
O! my czasem bicz z piasku ukręcić musimy
I tak ja dziś Józefa, dla większej estymy,
Pisząc życie, muszę się dobrze zastanowić,
Co tutaj powiedzieć, gdzie nie ma co mówić.
Tak to pracować musim i pracujem w pocie,
Inaczejby niechybnie świat zginął w ciemnocie ${ }^{59}$.

V

Józef Dunin Borkowski na nowo został odkryty dopiero w roku 1950, gdy nakładem Państwowego Instytutu Wydawniczego ukazał się wybór jego poezji, opracowany przez Adama Ważyka. Edytor podkreślił, że wprawdzie wkład Borkowskiego do naszej poezji nie jest obfity, ale autor

\ doszedł do nowatorstwa w cyklu sonetów, w których zjawia się rzecz niespotykana w naszej poezji - konkretny obraz obyczajowy miasta

58 Ż. Pauli, [b.t.], „Gazeta Lwowska”1843, nr 68, s. 450.

59 J.K. Pajgert, Zemsta Wandy. Poema satyryczno-żartobliwe w pięciu pieśniach, Poznań 1846, s. 39-40. 
z pierwszej połowy XIX wieku. To realistyczne osiągnięcie romantycznego poety jest najważniejszym powodem, dla którego daję tę książkę w ręce czytelnika ${ }^{60}$.

Nie mniejszą zasługą była z pewnością popularyzacja przez Józefa Borkowskiego ówczesnej kultury czytelniczej. Co więcej, zawdzięczamy mu ocalenie od zapomnienia poematu bohaterskiego Wojna Chocimska Wacława Potockiego. To właśnie Józef Borkowski „W przeddzień śmierci, kiedy już dogorywał, wręczył rękopis ten przyjacielowi swemu Stanisławowi Przyłęckiemu z obowiązkiem wydania go jak najrychlej" ${ }^{\prime \prime}$.

W lwowskim kościele Karmelitów, zamienionym w cerkiew św. Michała, ocalały - pro memoria - do naszych czasów resztki tablicy z napisem:

\section{》 Józef Hrabia Dunin Borkowski Poeta-Hellenofil \\ ur. 23 marca I809, zm. I8 czerwca I843 \\ Z kwiatów mam pióro, perłami łez piszę, \\ Myśl moja w morskiej podróży \\ $\mathrm{Na}$ archipelskich wyspach się kołysze, Jak złoty motyl na róży...}

Na zakończenie powyższych rozważań należy jednak stwierdzić ,że ten uznany swego czasu „poeta-hellenofil” nadal, niestety, nie zyskał właściwego mu miejsca w historii polskiej literatury. Adam Ważyk sformułował tezę, że autor Sonetów pettewnych dlatego jest pomijany w podręcznikach historii literatury, bo ubiegł pod pewnymi względami poezję zachodnią o „kilkadziesiąt lat” i psułby ustalony obraz romantyzmu polskiego ${ }^{62}$. Tezę tę powtórzyła po latach Bogumiła Kurzeja, twierdząc, że czytelnik po lekturze cyklu Sonetów pettewnych Józefa Borkowskiego

60 J. Dunin Borkowski, Wybór poezji, wyd. i oprac. A. Ważyk, Warszawa 1950, s. 8.

61 W.K. Wł. [Kazimierz Władysław Wójcicki], Borkowski (Józef Dunin), w: Encyklopedia powszechna S. Orgelbranda, t. 4, Warszawa 1860, s. 102. Książka wydana przez Stanisława Przyłęckiego Wojna chocimska. Poemat bohaterski (Lwów 1850) została mylnie opublikowana nakładem kuratora Zakładu Narodowego Ossolińskich - Henryka Lubomirskiego, jako utwór autorstwa Andrzeja Lipskiego podwojewodziego sandeckiego, podczaszego chetmskiego.

62 Zob. A. Ważyk, Bielmo na oczach, „Nowa Kultura” 1950, nr 1. 
szybko odnosi wrażenie, że romantycznemu poecie znacznie bliżej do pozytywizmu. Odbrązowienie wizerunku kobiety, miłości, rzeczywistości (a w niej mitu m.in. małej ojczyzny) i wyobrażeń o I połowie XIX wieku w ogóle skłania do porównania Borkowskiego z prozaikami nurtu realistycznego. [...] Nowością było niewątpliwie oryginalne ujęcie oblicza dziewiętnastowiecznego Lwowa i jego mieszkańców, ale w dużej mierze antyromantyczność znana np. z komediopisarstwa Aleksandra Fredry. Poetycka drwina z romantycznej poetyki, zestawienie tego, co poetyckie, z tym, co prozaiczne, kategoria ironii, żywioł mowy potocznej, urozmaicona akcja, zminimalizowana fikcja, pełna naturalności żartobliwość, zaakcentowanie kwestii społecznych i obyczajowych - wszystkie te czynniki zdecydowały o wyjątkowości cyklu ${ }^{63}$.

Trudno się oczywiście z powyższymi opiniami nie zgodzić i jednocześnie nie zauważyć tym samym jakby zderzenia owych tendencji realistycznych uobecniających się w twórczości Józefa Dunina Borkowskiego z „romantycznym”, pośmiertnym hołdem bliskich mu osób. Zderzenie to jest jednak tylko pozorne, gdyż w istocie romantyzm był „pewną szczególną formą racjonalności, a nie, jak to się zwykle u nas przedstawia, rozwichrzoną «romantycznością» przeciwstawioną «szkiełku i oku»" ${ }^{64}$. Wszyscy skupieni wokół Józefa Borkowskiego Ziewończycy byli propagatorami takiego właśnie „romantyzmu racjonalnego”.

\section{Bibliografia}

A. B. [August Bielowski], Przedstowie, w: Ziewonia, wyd. powtórne, pomnożone, Strasburg 1839.

Album na korzysć pogorzelców, wydane przez Józefa Dunina Borkowskiego, z portretem wydawcy, Lwów 1844 w 8 stron 251, „Biblioteka Warszawska” 1844, t. 4.

Anonim, Album. Pismo zbiorowe, na korzyśc pogorzelców wydane w Wiedniu przez Józefa Dunina Borkowskiego, 1844. W ósemce większej, stron 135. Wydanie ozdobne z wizerunkiem Józefa Dunina Borkowskiego, „Przegląd Naukowy” 1844, nr 17.

Anonim [W. Zawadzki], Leszek Dunin Borkowski, „Tygodnik Ilustrowany”1872, nr 223.

[b.a.], Pierwszy akt, „Dziennik Mód Paryskich”1848, nr 24.

[b.a.], Spis osób, które w biurze redakcji „Gazety Lwowskiej” przyczynity się do sktadek dla pogorzelców Żmigrodu, „Gazeta Lwowska” 1843, nr 59, s. 390; nr 62, s. 410; nr 65, s. 429; nr 68, s. 450; nr 70, s. 464; nr 73, s. 484 ; $\mathrm{nr} 76$, s. $502 ; \mathrm{nr} 79$, s. $522 ; \mathrm{nr} 85$, s. 562 .

[b.a.], Uwagi ogólne nad literatura w Galicji. (Dokończenie), „Tygodnik Literacki” 1842, nr 52.

Bielik-Robson A., Romantyzm, niedokończony projekt. Eseje, Kraków 2008.

63 B. Kurzeja, Dzierwiętnastowieczny Lwów..., s. 48.

64 A. Bielik-Robson, Romantyzm, niedokończony projekt. Eseje, Kraków 2008, s. 6. 
Bielowski A., Żywot Józefa hrabiego Dunina Borkowskiego, w: Album na korzyść pogorzelców. Wydane przez Józefa Dunina Borkowskiego, Lwów 1844.

Dunin Borkowski J., [inc.: „Pisarze nasi chcąc ze swojej strony przyczynić się do wsparcia pogorzelców galicyjskich...”], „Dziennik Mód Paryskich” 1842, nr 16.

Wybór poezji, wyd. i oprac. A. Ważyk, Warszawa 1950.

Dunin Borkowski L. , [b.t.], „Dziennik Mód Paryskich”1843, nr 14.

Estreicher K., Dziennikarstwo w Galicji i Krakowie. Do roku 1860, „Biblioteka Warszawska”1861, t. 2, z. 4.

Grabowski M., Pamiętniki o literaturze polskiej między 1830 a 1848. Literatura galicyjska, „Dziennik Warszawski" 1851, nr 101.

H. B., Józef Borkowski (1809-1843), w: Ztota przędza poetów i prozaików polskich, t. 2, red. P. Chmielowski, Warszawa 1885.

Janion M., Artysta romantyczny wobec narodowego sacrum, w: eadem, Czas formy otwartej: tematy i media romantyczne, Warszawa 1984.

Józef Dunin Borkowski, w: Literatura krajowa w okresie romantyzmu 1831-1863, t. 1, red. M. Janion,

B. Zakrzewski, M. Dernałowicz, Kraków 1975.

Jasińska M., Niestusznie zapomniany poeta - Józef Dunin Borkowski. (Próba charakterystyki twórczości), „Prace Polonistyczne” 1951, t. 9.

Kostkiewiczowa T., Mnemozyne i córki. Pamięć w literaturze polskiej drugiej potowy XVIII wieku, Toruń 2019.

Kurzeja B., Dziewiętnastowieczny Lwów i jego mieszkańcy w krzywym zwierciadle - na podstawie „Sonetów pettewnych” Józefa Dunina Borkowskiego, „Jednak Książki. Gdańskie Czasopismo Humanistyczne” 2014, nr 1.

Leszka hr. Dunina Borkowskiego autobiografia, „Dziennik Polski” 1897, nr 133.

Lisowski A.J., Rozmyślania spleenisty nad 68 numerem „Gazety Lwowskiej”, „Przyjaciel Ludu” 1843, nr 8.

Nowak J., Piastuni dziejów. Wizerunki narodów europejskich w polskiej refleksji romantycznej, Warszawa 2018.

Pajgert J.K., Zemsta Wandy. Poema satyryczno-żartobliwe w pięciu pieśniach, wyd. L. M., Poznań 1846.

Pauli Ż., [b.t.], „Gazeta Lwowska” 1843, nr 68.

Pypłacz J., Pięć stadiów żatoby w „Odzie” I.24 Horacego, „Biuletyn Biblioteki Jagiellońskiej” 2016, R. LXVI.

Rosnowska J., Twórcy „Dziennika Mód Paryskich”, „Rocznik Historii Czasopiśmiennictwa Polskiego” $1967, \mathrm{nr} 6 / 2$.

W. K. Wł. [Wójcicki Kazimierz Władysław], Borkowski (Józef Dunin), w: Encyklopedia powszechna S. Orgelbranda, t. 4, Warszawa 1860.

Walicka K., Józef Dunin Borkowski i jego poetycka twórczośc. (Wobec nowego wydania A. Ważyka), „Prace Polonistyczne" 1952, seria X.

Ważyk A., Bielmo na oczach, „Nowa Kultura” 1950, nr 1.

Wilkoń A., Dzieje języka artystycznego w Polsce. Renesans, Katowice 2004.

Wójcicki K.W., Wspomnienie o Józefie Dzierzkowskim, „Tygodnik Ilustrowany” 1865, nr 284.

SŁOwa Klucze: Aleksander Dunin Borkowski, Józef Dunin Borkowski, Ziewończycy, romantyzm, poezja funeralna 


\section{Tadeusz Póєchєopek}

\section{THE LITERARY TRIBUTE OF GALICIAN POETS TO Józef DUNIN BorkowsKi}

The article is devoted to one of the most outstanding figures of Polish 'domestic' Galician Romanticism - Józef Dunin Borkowski - about whom Anna Opacka wrote as of a 'wrongfully forgotten poet'. The premature death of the animator of romanticising trends in Lviv (he lived just 34 years, died I8th June I843) has disorganised the unity of the whole environment and disrupted the preparations for Album na korzyśc pogorzelców, announced by the deceased. The comrades of the poet's 'literary employment' commemorate him in an extraordinary tribute: his younger brother - Aleksander Dunin Borkowski - has completed (in I844) the edition of the aforementioned album. It contained not only the artistic pieces given to this charitable initiative by the most important authors of the time, but also the intimate farewells to the deceased editor. And, it is exactly these texts, which hold the greatest value for history of literature, which became the subject of our exploration. August Bielowski, after the funeral, wrote an amicable recollection, which was, nota bene, an inestimable source of knowledge on the beginnings of Galician Romanticism. The second text, also an important testimony of remembrance, was an emotional poem written by Aleksander Dunin Borkowski, and which is a unique example of romantic funerary poetry.

KeY words: Józef Dunin Borkowski, Aleksander Dunin Borkowski, Ziewończycy, Romanticism, funerary poetry 